\title{
Spatial Distribution of Insect Diversity in Selected Locations within Forestry Research Institute of Nigeria, Ibadan, Nigeria
}

\section{*AINA-ODUNTAN, OA; ONILUDE, QA; GEORGE-ONAHO, JA; WOGHIREN, AI; JEMINIWA, OR}

\author{
Forestry Research Institute of Nigeria, P.M.B 5054, Jericho Hill, Ibadan, Oyo State, Nigeria
}

*Corresponding Author Email: harkinlarbee@gmail.com;Tel: +2348035622694

\begin{abstract}
With the increase in the rate of tree removal and construction of buildings within the Forestry Research Institute of Nigeria premises, there has been concomitant rise in habitat modification. These changes in habitat composition affect the insect population. This study therefore investigated the insect species diversity and abundance within some selected locations within FRIN with the view to determining different insect species available in FRIN premises. Sweep nets were used to trap the insects along a predetermined line transect. Data were analyzed using Microsoft Excel 2007 and Paleontological Statistics were used for the data analysis. Descriptive statistics, one-way analysis of variance (ANOVA) and species diversity and composition were all assessed. A total number of 1073 individual insects belonging to 6 orders, 27 families and 34 species were recorded across the three locations. Out of this, Order Lepidoptera had the highest relative abundance (53\%), followed by Coleoptera (22\%), then by Hymenoptera, Hemiptera, Heteroptera and Diptera with $10 \%, 9 \%, 4 \%$ and $2 \%$ relative abundance respectively. The result of ANOVA showed that there was no significant difference in species composition/richness across the locations at probability level of 5\%. The insect species diversity, evenness and richness also varied across the locations. This study therefore, brings to the fore the diversity and abundance of insects within FRIN premises and highlighted the need for a more intensive study by the entomology section and for sustainable actions to be taken in conserving beneficial rare species while, managing the abundant pestiferous ones.
\end{abstract}

\section{DOI: https://dx.doi.org/10.4314/jasem.v25i7.21}

Copyright: Copyright $(0) 2021$ Aina-Oduntan et al. This is an open access article distributed under the Creative Commons Attribution License (CCL), which permits unrestricted use, distribution, and reproduction in any medium, provided the original work is properly cited.

Dates: Received: 10 May 2021; Revised: 28 June 2021; Accepted: 01 July 2021

Keywords: Football field, forestry arboretum, herbal garden, insect diversity, spatial distribution

It is common knowledge among entomologists who have been engaging in insect collection that insect species diversity, abundance and composition vary greatly between adjacent locations. Sometimes, even between areas of great differences in the length and intensity of the seasons. Insects are important because of their diversity, ecological role, and influence on agriculture, human health and natural resources (Berenhaum, 1995; Adetundan et al., 2005; Premalatha et al., 2011).The total number of insect species on earth is estimated to be 1-3 million, probably represents more than $80-90 \%$ of all animal species (FAO, 2013; Yang et al., 2016; Jansson and Berggren, 2015 and Glick and Miller, 2016). Insects are the most populated organisms in the world (Speight et al., 2008). This can be because different species of the insect reproduces very fast and have large number of offspring. They are highly sensitive to changes in climate of their environment, such as rainfall, temperature, wind humidity and altitude (Khaliq et al., 2014). Insect are very important in natural as well as constructed landscapes. Insects are closely associated with human lives and have great impact on the welfare of humanity in diverse ways. They play crucial role in diverse ecosystem services especially in agriculture, tourism and in natural resource use (Choi and Miller, 2013). In the same vein, large numbers of insect species, including those not known to science, continue to become extinct from local habitats world-wide (Miller and Rogo, 2001). The diversity of insect species is a function of the environmental condition (Yi et al., 2012). Habitat loss poses the greatest threat to the long-term survival of species on earth. Habitat fragmentation (the reduction of continuous habitat into several smaller spatially isolated remnants.), decreases area, increase edge. Jericho is a richly agrarian community in the southern part of Ibadan in Oyo state. The diversity and abundance of insects in this area has hardly been studied. Insect biodiversity studies conducted in Nigeria have largely been on the insects' diversity of specific orders and or species of insects. Few have considered the insect community altogether (Meddler, 1980). Aside inadequate taxonomic knowledge, the ecological knowledge of insects in Nigeria is not well understood as distribution and abundance of many insects species in the country are unknown and ecosystem services mostly assumed (Kato et al., 2000). Anthropogenic activities have contributed to the movement and spread of invasive insects into different habitats with many of them having Agricultural and Veterinary implications (Wardle, 2002). The total area vegetation of Forestry research institute of Nigeria has been seriously fragmented and 
modified through the construction of buildings and road networks. The establishment and fencing of the herbal garden also has an impact on insect species distribution within FRIN. Even some of the fragmented areas are being further modified through the introduction of different land use and land cover types. This continues having serious impacts on FRIN landscape. However, little attention has been given to ascertain the impact of habitat fragmentation, modification and loss, on the composition and diversity of the insect populations. Disappearance of insects could lead to extinction of earth's animals because of the disappearance of so much plant life (Yager et al., 2017). Today insects are by far the planet's most diverse, abundant and successful species (Zrzavy, 2018). The positive and negative roles of insects in nature require proper understanding on how they interact with living and non-living environment and their diversity (Miller, 2006). The current study is designed for the very first time to provide and document a checklist of the insects found in each of the locations, determine their composition and diversity pattern within the study locations. The information that will be provided will be useful in giving an insight to insect species richness in the institute over the years, an information that is very useful for the management and conservation purposes (Mazon and Bordera, 2008).

\section{MATERIALS AND METHODS}

Study area: The study was carried out at different locations within the Forestry Research Institute of Nigeria Jericho Hill, Ibadan, Nigeria. The locations are Forestry Arboretum (FA), College of Forestry football field (COFF) and the Herbal Garden (HG). FRIN is located between latitude $07^{\circ} 25^{\prime} \mathrm{N}$ and $07^{\circ}$ $55^{\prime} \mathrm{N}$ and longitude $3^{\circ} 9^{\prime} \mathrm{E}$ and $53^{\circ} \mathrm{E}$. The annual temperature ranges between $18.7^{\circ} \mathrm{C}$ and $34.4^{\circ} \mathrm{C}$. The region is characterized with bimodal pattern of rainfall with peaks in July and September with mean annual rainfall of $1420.106 \mathrm{~mm}$. The mean relative humidity was $82 \%$ between June and September and 60\% between December and February (FRIN meteorological station). The location of the study site is presented in figure 1 .

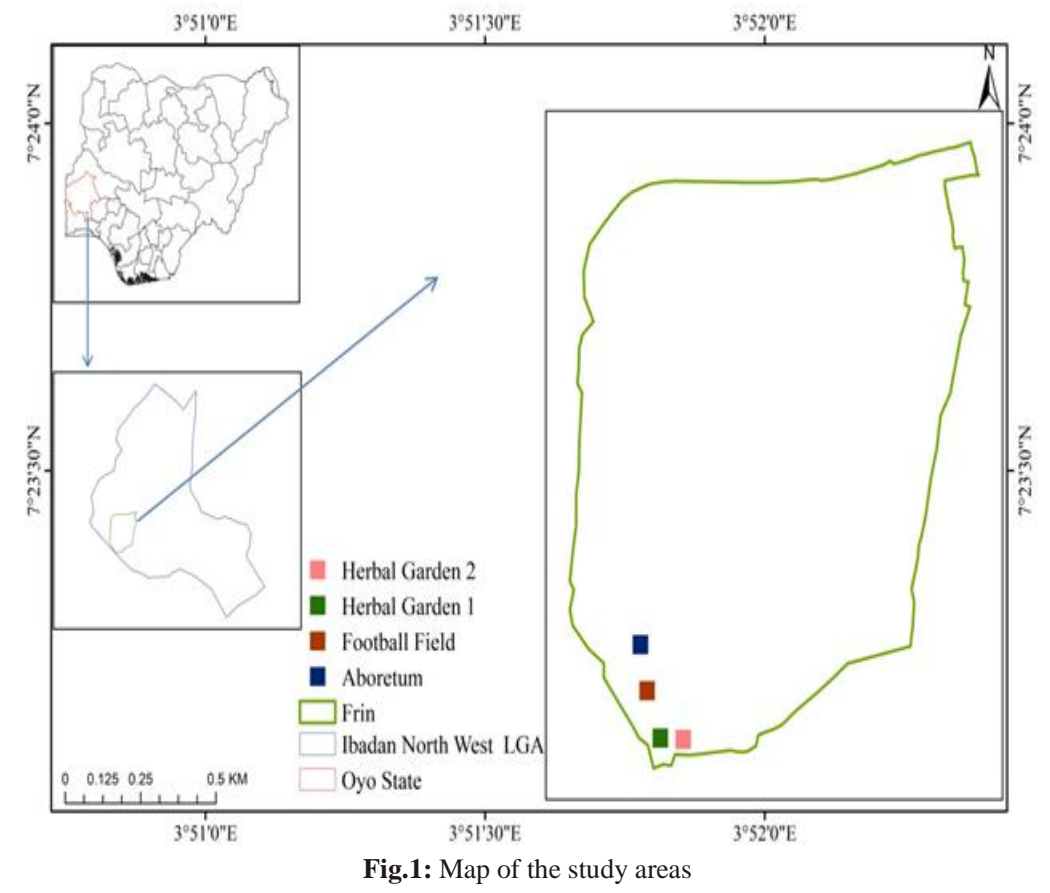

Sampling Procedure: The selected study areas were selected within the Forestry Research Institute of Nigeria premises based on the availability of tree species in the locations which can serve as host to these insect species. The areas included the forestry arboretum (FA), College of Forestry football field (COFF) and the herbal garden (HG).

Method of insect collection: This study made use of Sweep method of sampling technique across the three locations within FRIN. This method is suitable for sampling insects from ground layer vegetation. The sweeps were done during the early hours of the day between 6 am to 10 am and evening from 4 pm to 7 pm twice in a week, along an established 200M transect line. The insects collected were killed using ethyl acetate and temporarily kept in polythene bags and plastic containers and later taken to the laboratory for identification and preservation.

Preservation and Identification of insects collected: All insects collected were preserved by immersion in $70 \%$ ethanol. However, insects like moths that have scales on their wings were preserved dry in a tight container containing Silica gel. Representative samples were preserved in the Biological Laboratory 
of the Entomology section of the Forestry Research Institute of Nigeria for future reference. All insects collected were taken for identification at the Entomology section of the Forestry Research Institute of Nigeria.

Data Analysis: Data gathered for this research were analyzed using both descriptive and inferential statistics. Descriptive statistics like frequencies and percentages were used while One-way analysis of variance was employed as inferential statistics. Identified insects species were grouped into Order, Family and species. Species Diversity and Distribution were computed using diversity indices such as species diversity, species richness and evenness. However, insect species that couldn't be identified on the field was taken to Forestry Research Institute of Nigeria (FRIN) entomology department for proper identification. Data collected was put to statistical analysis to obtain meaningful information which can be used for managerial policy and decision making by the FRIN management. All the analyses in the study were done using Microsoft Excel 2007 (Microsoft Corp., Redmond, WA, USA) and Paleontological Statistics software package for education and data analysis (PAST).

\section{RESULTS AND DISCUSSION}

Diversity and Abundance of insects in the study locations: Table 1 show the diversity and abundance of insect species identified in the selected locations. A total of 1,703 individual insect samples were identified and collected for the study as presented in table 1 belonging 6 orders, 27 families and 34 species (Table 1). The largest number of insect species (27) for the study was observed from Forestry Herbarium $(\mathrm{FH})$, followed by Herbal Garden (HG) (26) while the least was observed in College of Forestry Football Field (22). Across the locations, Hypolimnus misippus had the highest abundance (143) in the Order Lepidoptera and family Nymphalidae, followed by Sinoxylon senegalense (124) and Bombyx mori (108) while the least abundant (rare) insect species include Trochalus gibbus, Pachnoda cordata and Xylopertheila picea, all in the Order Coleoptera (Table 1). Table 2 shows the relative abundance of the insect species in the selected locations. Hypolimnas misippus had the highest relative abundance of $(8.4 \%)$ followed by Sinoxylon senegalense with (7.28\%) and Bombyx mori (6.34\%) while insect with least relative abundance were Trochalus gibbus $(0.53 \%)$, Pachnoda cordata and Phryneta leprosa having $0.59 \%$.

Table 1: Diversity and Abundance Insect species in the study areas

\begin{tabular}{|c|c|c|c|c|c|c|c|c|}
\hline \multirow[t]{2}{*}{$\mathbf{S} / \mathbf{N}$} & \multirow[t]{2}{*}{ Order } & \multirow[t]{2}{*}{ Family } & \multirow[t]{2}{*}{ Species } & \multirow[t]{2}{*}{ Host Plant } & \multicolumn{3}{|c|}{ Location } & \multirow[t]{2}{*}{ TOTAI } \\
\hline & & & & & FH & COFF & HG & \\
\hline 1 & \multirow[t]{10}{*}{ Coleoptera } & Scarabaeidae & Pachnoda cordata & Anacardium ocidentalis & 10 & 0 & 0 & 10 \\
\hline 2 & & Scarabaeidae & Trochalus gibbus & No name & 9 & 0 & 0 & 9 \\
\hline 3 & & Bostrichidae & Sinoxylon senegalense & bamboo & 70 & 43 & 11 & 124 \\
\hline 4 & & Bostrichidae & Xylopertheila picea & No name & 11 & 0 & 0 & 11 \\
\hline 5 & & Tenebrionidae & Alphitobius Spp & No name & 2 & 55 & 12 & 69 \\
\hline 6 & & Elateridae & Selasia unicolor & No name & 10 & 77 & 9 & 96 \\
\hline 7 & & cerambycidae & Phryneta leprosa & Modus alba & 2 & 0 & 8 & 10 \\
\hline 8 & & Platypodidae & Platypus hintzi & Antiaris africana & 0 & 0 & 29 & 29 \\
\hline 9 & & Scolytidae & Xyleborus perforans & Eucalyptus Spp & 2 & 0 & 13 & 15 \\
\hline 10 & & Bostrichidae & Apate monachus & Terminalia catappa & 0 & 0 & 11 & 11 \\
\hline 11 & \multirow[t]{5}{*}{ Hymenoptera } & Vespidae & Belonogaster juncea & Anacardium ocidentalis & 7 & 29 & 8 & 44 \\
\hline 12 & & Formicidae & Camponotus Spp & Anacardium ocidentalis & 22 & 0 & 31 & 53 \\
\hline 13 & & Formicidae & Crematoguster depressa & No name & 0 & 22 & 21 & 43 \\
\hline 14 & & Apidae & Xylocopa Spp & No name & 30 & 0 & 9 & 39 \\
\hline \multicolumn{8}{|c|}{ - } & \\
\hline 16 & Diptera & Stratiomyidae & Hermetia ilucens & No name & 30 & 0 & 0 & 30 \\
\hline \multicolumn{9}{|c|}{ ค } \\
\hline 18 & \multirow[t]{3}{*}{ Heteroptera } & Cydidae & Cydnus Spp & Anacardium ocidentalis & 30 & 11 & 7 & 48 \\
\hline 19 & & Reduviidae & Physorhynchus distinctus & No name & 0 & 11 & 1 & 12 \\
\hline \multicolumn{8}{|c|}{ 20 } & \\
\hline 21 & \multirow[t]{14}{*}{ Lepidoptera } & Nymphalidae & Phalanta phalantha & Populous euphratica & 12 & 6 & 0 & 18 \\
\hline 22 & & Crambidae & Haritalodes derogata & Hibiscus Spp & 55 & 13 & 8 & 76 \\
\hline 23 & & Nototindae & Anaphe venata & Triplochiton scleroxylon & 21 & 80 & 3 & 104 \\
\hline 24 & & Noctuidae & Magusa versicolorra & Triplochiton scleroxylon & 11 & 2 & 3 & 16 \\
\hline 25 & & Papilionidae & Papilio demodocus & Anacardium ocidentalis & 80 & 14 & 0 & 94 \\
\hline 26 & & Nymphalidae & Hypolimnas misippus & Anacardium ocidentalis & 97 & 6 & 40 & 143 \\
\hline 27 & & Geometridae & Zamara Spp & No name & 32 & 8 & 51 & 91 \\
\hline 28 & & Erebidae & Estigmene acrea & Pisum sativum & 0 & 23 & 0 & 23 \\
\hline 29 & & Bombycidae & Bombyx mori & Modus rubra & 20 & 88 & 0 & 108 \\
\hline 30 & & Erebidae & Crotema mentiens & Terminalia ivorensis & 11 & 21 & 37 & 69 \\
\hline 31 & & Erebidae & Euproctis Spp & Triplochiton scleroxylon & 8 & 0 & 8 & 16 \\
\hline 32 & & Pyralidae & Sylepta derogata & Solanum gilo & 0 & 11 & 40 & 51 \\
\hline 33 & & Limacodidae & Parade euchlora & No name & 21 & 11 & 3 & 35 \\
\hline 34 & & Nymphalidae & Acraea igola & No name & 8 & 12 & 31 & 51 \\
\hline 35 & \multirow[t]{4}{*}{ Hemiptera } & Perrhocoridae & Dysdercus superstitious & Ceiba pentandra & 8 & 32 & 15 & 55 \\
\hline 36 & & Pentatomidae & Aspavia armigera & Modus alba & 10 & 47 & 11 & 68 \\
\hline \multirow[t]{2}{*}{37} & & Coreidae & Leptoglossus membranaceus & Anacardium ocidentalis & 0 & 0 & 32 & 32 \\
\hline & & & & Total & 629 & 622 & 452 & 1703 \\
\hline
\end{tabular}


Percentage frequency distribution of the individual insects and the species based on insect Order: According to the total number of species, the dominant order was the Lepidoptera with 11 families and 14 species (Fig. 1), followed by Coleoptera (7 families and 10 species), Hymenoptera (3 families and 4 species), Hemiptera (3 families and 3 species), Heteroptera (2 familes and 2 species) and the least was Diptera with 1 family and 1 species (Fig. 1). Also, table 2 revealed the percentage distribution of the individual insect and insect species in each of the study locations based on Order. In FA, the insect Order with the highest percentage distribution was Diptera (54\%), followed by Lepidoptera $(21 \%)$ while the Order with least percentage distribution was Heteroptera with $2 \%$. In COFF, Lepidoptera had the highest percentage distribution $(59 \%)$, followed by Coleoptera (14\%), followed by Hemiptera, Heteroptera and Hymenoptera with $2 \%$ distribution each while Diptera had no representative. In $\mathrm{HG}$, Lepidoptera had $38 \%$ distribution, followed by Coleoptera (27\%), Hemiptera, Heteroptera and Hymenoptera had 12\%, $8 \%$ and $15 \%$ distribution respectively while Diptera was not found in the location (Table 3). However, for the individual insect species, out of the 689 individual insect species found in Forestry Herbarium, 55\% belongs to Lepidoptera, $17 \%$ belongs Coleoptera and Hymenoptera while the least was Hemiptera (3\%). In COFF, Lepidoptera had the highest distribution with $46 \%$ followed by Coleoptera $27 \%$ while the least was Heteroptera (4\%) with no representative for Diptera (Table 3). In the HG, out of the 460 insects identified,

Lepidoptera had the highest distribution (48\%), followed by Coleoptera $(20 \%)$ while the least was Heteroptera $(2 \%)$.

Table 2: Relative abundance of the insect species identified across the

\begin{tabular}{clc}
\multicolumn{3}{c}{ study locations } \\
\hline S/N & Speices & R A (\%) \\
\hline 1 & Pachnoda cordata & 0.59 \\
2 & Trochalus gibbus & 0.53 \\
3 & Sinoxylon senegalense & 7.28 \\
4 & Xylopertheila picea & 0.65 \\
5 & Alphitobius Spp & 4.05 \\
6 & Selasia unicolor & 5.64 \\
7 & Phryneta leprosa & 0.59 \\
8 & Platypus hintzi & 1.70 \\
9 & Xyleborus perforans & 0.88 \\
10 & Apate monachus & 0.65 \\
11 & Belonogaster juncea & 2.58 \\
12 & Camponotus Spp & 3.11 \\
13 & Crematoguster depressa & 2.52 \\
14 & Xylocopa Spp & 2.29 \\
15 & Hermetia ilucens & 1.76 \\
16 & Cydnus Spp & 2.82 \\
17 & Physorhynchus distinctus & 0.70 \\
18 & Phalanta phalantha & 1.06 \\
19 & Haritalodes derogata & 4.46 \\
20 & Anaphe venata & 6.11 \\
21 & Magusa versicolorra & 0.94 \\
22 & Papilio demodocus & 5.52 \\
23 & Hypolimnas misippus & 8.40 \\
24 & Zamara Spp & 5.34 \\
25 & Estigmene acrea & 1.35 \\
26 & Bombyx mori & 6.34 \\
27 & Crotema mentiens & 4.05 \\
28 & Euproctis Spp & 0.94 \\
29 & Sylepta derogata & 2.99 \\
30 & Parade euchlora & 2.06 \\
31 & Acraea igola & 2.99 \\
32 & Dysdercus superstitious & 3.23 \\
33 & Aspavia armigera & 3.99 \\
34 & Leptoglossus membranaceus & 1.88 \\
& & $\mathbf{1 0 0 . 0 0}$ \\
\hline & Note: RA- Relative Abundance \\
& &
\end{tabular}

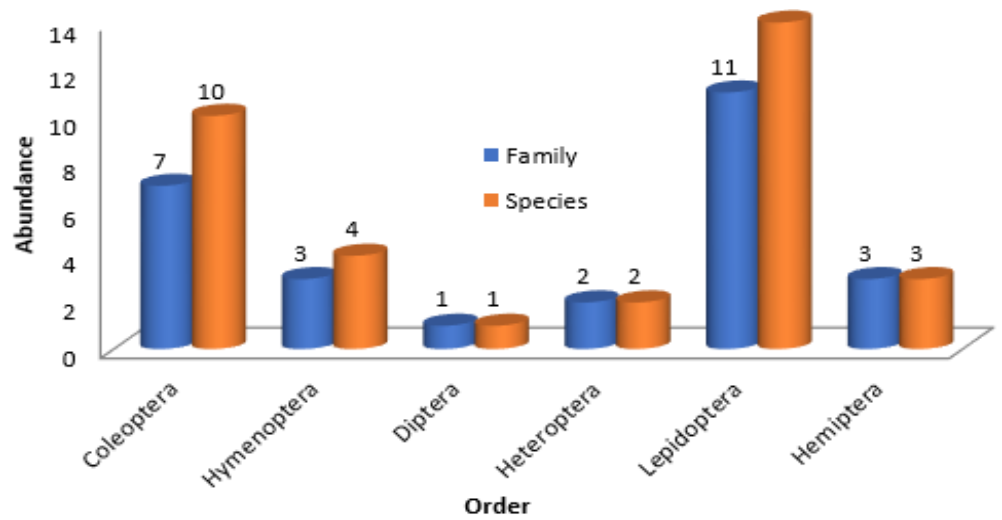

Fig. 1: Family and insect species abundance based on the insect Order

Table 3: Percentage distribution of individual insects (Frequency) and the species based on Order for the three study locations

\begin{tabular}{llllllll}
\hline S/N & Order & \multicolumn{3}{c}{ Species } & \multicolumn{2}{c}{ Individual } \\
\cline { 3 - 7 } & & FH & COFF & HG & FH & COFF & HG \\
\hline 1 & Coleoptera & $8(14 \%)$ & $3(14 \%)$ & $7(27 \%)$ & $116(17 \%)$ & $175(27 \%)$ & $93(20 \%)$ \\
2 & Diptera & $30(54 \%)$ & $0(0 \%)$ & $0(0 \%)$ & $30(4 \%)$ & $0(0 \%)$ & $0(0 \%)$ \\
3 & Hemiptera & $2(4 \%)$ & $2(9 \%)$ & $3(12 \%)$ & $18(3 \%)$ & $79(12 \%)$ & $58(13 \%)$ \\
4 & Heteroptera & $1(2 \%)$ & $2(9 \%)$ & $2(8 \%)$ & $30(4 \%)$ & $22(4 \%)$ & $8(2 \%)$ \\
5 & Hymenoptera & $3(5 \%)$ & $2(9 \%)$ & $4(15 \%)$ & $119(17 \%)$ & $73(11 \%)$ & $77(17 \%)$ \\
6 & Lepidoptera & $12(21 \%)$ & $13(59 \%)$ & $10(38 \%)$ & $376(55 \%)$ & $295(46 \%)$ & $224(48 \%)$ \\
& Total & $\mathbf{5 6}(\mathbf{1 0 0})$ & $\mathbf{2 2}(\mathbf{1 0 0})$ & $\mathbf{2 6}(\mathbf{1 0 0})$ & $\mathbf{6 8 9}(\mathbf{1 0 0})$ & $\mathbf{6 4 4}(\mathbf{1 0 0})$ & $\mathbf{4 6 0}(\mathbf{1 0 0})$ \\
\hline \multicolumn{6}{c}{ Note: FH- Forestry Herbarium, COFF- College of Forestry Football Field, HG- Herbal Garden }
\end{tabular}

Relative abundance of the Orders: Across the study locations, Fig. 2 shows the pooled relative abundance of insects based on Orders. Out of the total insects identified, Order Lepidoptera had the highest relative abundance (53\%), followed by Coleoptera (22\%), then 
by Hymenoptera, Hemiptera, Heteroptera and Diptera with $10 \%, 9 \%, 4 \%$ and $2 \%$ respectively.

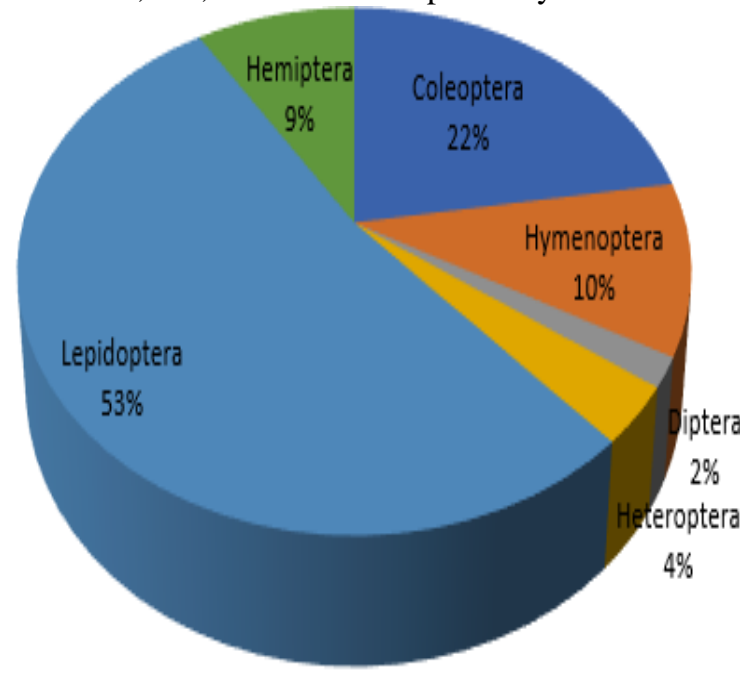

Fig. 2: Pooled percentage distribution of the insect orders across the selected locations

The result of the insect species diversity for the study locations as presented in (Table 4) revealed that the HG had the highest value for insect diversity $\left(\mathrm{H}^{\prime}=\right.$
2.956), followed by $\mathrm{FH}\left(\mathrm{H}^{\prime}=2.866\right)$ and the least with $\left(\mathrm{H}^{\prime}=2.735\right)$ in COFF.

Table 4: Diversity indices of insects in the study locations

\begin{tabular}{llll}
\hline Variables & \multicolumn{3}{l}{ Locations } \\
\cline { 2 - 4 } & FA & COFF & HG \\
\hline Number of species & 27 & 22 & 26 \\
Individuals & 629 & 622 & 452 \\
Shannon_H & 2.866 & 2.735 & 2.956 \\
Dominance_D & 0.07675 & 0.0817 & 0.06262 \\
Species eveness & 0.6509 & 0.7007 & 0.7395 \\
Margalef index & 4.035 & 3.264 & 4.087 \\
\hline Note: FH- Forestry Herbarium; COFF-College of Forestry \\
Football Field; HG- Herbal Garden
\end{tabular}

The highest species evenness was observed in $\mathrm{HG}$ (0.7395), followed by COFF (0.7007) and the least observed in FA (0.6509). The Shannon diversity t-test revealed that there is a significant difference $(\mathrm{P} \leq 0.05)$ between FA and COFF and between COFF and HG in terms of species diversity. However, there is no significant difference $(\mathrm{P}>0.05)$ between FA and HG in term of species diversity (Table 5). The result of One-way ANOVA launched from the PAST revealed in Table 6 that there was no significant difference in species composition/richness across habitat at probability level of $5 \%$.

Table 5: P-values for Shannon diversity t-test showing the level of difference in insect diversity between the study locations

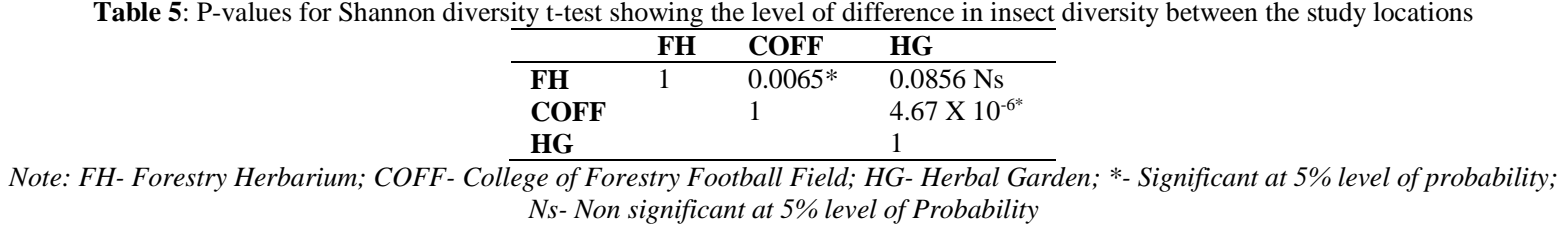

\begin{tabular}{llllll}
\multicolumn{5}{c}{ Table 6: One-way ANOVA difference in species composition across habitat } \\
\hline Variables & Sum of Square & Degree of Freedom & Mean Square & F & P-Value \\
\hline Between groups & 590.961 & 2 & 295.480 & 0.6395 & $0.5297 \mathrm{~ns}$ \\
Within groups & 45742.6 & 99 & 462.047 & & \\
Total & 46333.6 & 101 & & \\
\hline \multicolumn{6}{c}{ Note: No significant difference at probability level of 5\% }
\end{tabular}

The results of this study showed that the Forestry Research Institute of Nigeria has high insect diversity within her perimeter fencing. The rich number of species available in the study areas could be mainly because of availability of different tree species that can serve as hosts for these insects. The study locations environment contains ornamental plants and seedlings as well as vegetation cover that mimic a forest suitable for the growth and development of these insect species. This is in agreement with the result of Yager et al., (2017) who reported the same in their study of insect diversity at the Federal University of Agriculture Makurdi, Benue State, Nigeria.

The result obtained for the study revealed that the Order Lepidoptera was the most dominating order based on the individual insect species. This finding is in contrast with the result of Nandini and Murali (2012) and Yager et al. (2017) who reported Hymenoptera as the most dominating order in their study of insect species in Gulbarga District, Kamataka, India and Hemiptera in their study of insect abundance in the Federal Unibersity of Makurdi, Benue State,
Nigeria respectively. Also, this result negate the findings of Adeduntan and Olusola (2013) who presented Orthoptera as the most dominating insect Order in different forest vegetation types in Ondo State. However, these variations can be attributed to the difference in study locations and in environmental characteristics/attributes, and also could be the availability of susceptible hosts $n$ the study environments. The abiotic factors like the temperature, light and humidity do significantly influence the insects and the changes in their population trend, likewise the biotic factors (e.g. Host, crowding, diets etc.). Moreover, Heteroptera and Diptera Orders were the Orders with least number of individual insect species. This is in conformity with the report of Alarape et al., (2015) who stated that the abundance of individual insect species on a temporal scale was highly dependent on abiotic and biotic environment factors. The species of Lepidoptera identified in this study were typical of West African taxa. The species were in the families Nymphalidae, Papilionidae, Geometridae, Crambidae etc. This study revealed that 
the existence of tree species that can serve as host for these insects could make the Order Lepidoptera dominant in the study areas. Tree species that served as host to this order in the study areas included Triplochiton scleroxylon, Anacardium ocidentalis, Terminalia ivorensis etc. This is in line with the result of Nwosu and Iwu (2011) who observed more species of butterflies in the protected area of Okwu Ogbaku forest reserve in Imo State being attracted by the high presence of tree species in the reserve. Insect diversity indices of the study locations were examined to understand the insect diversity. The highest values of the Shannon-Weiner diversity observed in HG revealed a location with high insect species diversity and abundance. This Shannon-Weiner index compare favorably within the range of 2.87-3.20 reported by Yager et al., (2017) for insect species diversity and abundance in and around Federal University of Agriculture, Makurdi Forestry Nursery, Benue State, Nigeria. The result of the diversity indices across the study locations revealed that herbal garden (HG) > Forestry Arboretum (FA) > College of Forestry football field (COFF). Although, the difference between Shannon-Weiner values of FA and the HG is not much. This might be as a result high number of tree species present in the two study locations that can serve as hosts to the insect species. The result of Shannon diversity t-test showed that there were significant differences between FA and COFF; and COFF and $\mathrm{HG}$ while there was no significant difference between FA and HG at probability level of $5 \%$. However, this might be as a result of presence of trees between the two significant locations and viceversa. Although, the FA and HG were more similar in insect species composition, the ANOVA showed there was no significant difference in species composition/ richness across the study locations. This is however, clearly understood from the perspective that both FA and HG contains high number of tree species and it is believed that plants co-evolve with their insect herbivores as opined by Hougen and Rausher (2007) and Tscharntke and Brand (2004). This can also be attributed to the continuous availability of growth and development resources in the study locations which makes the environment conducive for breeding unlike the college of Forestry Football filed that do not contain any tree. This finding agrees with the results of Adeduntan and Olusola (2013) and Samways (2007) who reported that insects are always present where there is a favorable condition for their survival.

Conclusion: FRIN is rich in insect species biodiversity. The study provides baseline information on insects' species for documentation and for more research to be built on. The present list of insects' species from this study is not exhaustive and so further exploration of insects species be continued taking into consideration other methods of insect collection and seasonal variations, as it affects insects' population dynamics. It is recommended that management strategies towards conservation of both flora and insects species should be intensified at the study locations within FRIN.

\section{REFERENCES}

Adetundan, SA; Ofuya, TI; Fuwape, JA (2005). Environmental Effects of Insects' Herbivores and Logging On Tree Species Diversity In Akure Forest Reserve (Apomu)", Nigeria Appl Trop Agric, 9(1\&2):12-18

Adeduntan, SA; Olusola, JA (2013). Diversity And Abundance Of Arthropods And Tree Species As Influenced By Different Forest Vegetation Types In Ondo State, Nigeria. Int J Of Ecosystem. (3):1923

Alarape, AA; James, KO; Georgina, SM (2015). Butterfly Species Diversity And Abundance In University Of Ibadan Botanical Garden. Nigeria Open Journal Of Ecology. 5:352-360

Berenhaum, Mr (1995). Bugs In The System: Insect And Their Impact On Human Affair, Addison Wesley Publishing, 296p.

Choi, SW; Miller, JC (2013). Species Richness And Abundance Among Macromoths: A Comparison Of Taxonomic, Temporal And Spatial Patterns In Oregon And South Korea. The Entomological Society Of Korea And Wiley Publishing Asia Pty Ltd

Food And Agricultural Organization (2013). Edible Insects: Future Prospects For Food And Feed Security. Forestry Paper. 171:1-154

Glick, J; Miller, K (2016). Insect Classification With Heirarchical Deep. Convolutional Neural Networks Convolutional Neural Networks For Visual Recognition (Cs231n) Stanford University Final Report, Team Id: 283

Jansson, A; Berggren, A (2015). Insects As Food Something For The Future? A Report From Future Agriculture. Uppsala, Swedish University Of Agricultural Sciences (Slu). Isbn: 978-91-5769335-8

Kato, M; Itioka, T; Sakai, S; Monose, K; Yamane, S; Hamid, AA; Inoue, T (2000). Various Population Fluctuation Patterns Of Light Attracted Beetle In A Tropical Lowland Dipterocarp Forest In Sarawak, Populat Eco, 42:97-104

Khaliq, Am; Javed, MS; Muhammad, S (2014). Environmental Effects On Insects And Their Population Dynamics. J Of Entom And Zool Studies. 2(2):1-7 
Mazon M; Bordera, S. (2008). Effectiveness Of Two Sampling Methods Used For Collecting Tchneumonidae (Hymenoptera) In The Cabaneros National Park (Spain), Eur J Entomol, 105:879888

Meddler, JT (1980). Insect Of Nigeria Checklist And Bibiolography", Memoir Of American Entomological Institute. 919p.

Miller, GT (2006). Environmental Science, Working With Earth. 10th Edition, Brooks Cole Thompson, Nelson. 5 (25)

Miller, SE; Rogo, LM (2001). Challenges And Opportunities In Understanding And Utilization Of African Insect Diversity, Cimbebasia, 17:197-218

Nandini, VB; Murali, JA (2012). Preliminary Study On Abundance And Diversity Of Insect Fauna In Gulbarga District, Karnataka, India. Int. J. Sci. Res. $3(12)$

Nwosu, LC; Iwu, CJ (2011). A Comparative Study Of Diversity Of Species Of Butterflies In Protected And Unprotected Habitats Of Okwu Ogbaku Forest Reserve In Mbaitoli L.G.A., Imo State, Nigeria. J. Environ. Issue. Agric. Develop. Countries. 3(1):129-135

Okrikata, E; Yusuf, OA (2019). Study on The Diversity And Relative Abundance Of Insect Fauna In Wukari, Taraba State, Nigeria. Inter. J. Adv. Biol. Biomed. Res. 7(2), 129-141

Premalatha, M; Abbasi, T; Abassi, SA. (2011). Energy Efficient Food Production To Reduce Global Warming Eco-Degradation: The Use Of Edible Insects, Renew Sustain Energy Rev, 15(9):43574360
Samways, MJ (2007). Connecting Biodiversity: Trends In Ecology And Evolution. 22pp

Speight, MR; Hunter, MD; Watt, AD (2008). Ecology Of Insects: Concepts And Applications. Wiley Blackwell, West Sussex, Uk; 2008

Tscharntke, T; Brand R (2004). Plant-Insect Interactions In Fragmented Landscapes. Annual Review Of Entomology. 49:405-30. 41

Wardle, Da (2002). Community And Ecosystem Linking The Above And Below Ground Components. Princeton University Press, Princeton New Jersey. 392p

Yager, GO; Agbidye, FS; Okoh AO (2016). Diversity And Abundance Of Butterfly Species (Lepidoptera) Fauna In Federal University Of Agriculture, Makurdi Forestry Nursery, Benue State, Nigeria. J. Res In Forestry. Wildlife. Environ. 8(3):83-89

Yager, GO; Agbidye, FS; Adma, ES (2017). Insect Species Diversity and Abundance In and Around Federal University Of Agriculture, Makurdi, Forestry Nursery, Benue State, Nigeria. Asian J Bio 4(4): 1-11

Yi, Z; CC (2012). A Comparison of Terrestrial Arthropods Sampling Methods, J Res Ecology, 3:174-182

Zrzavy, J (2008). Four Chapters About The Monophyly Of Insect 'Orders': A Review Of Recent Phylogenetic Contributions. Acta Entomologica Musei Nationalis Pragae. 48(2):217232 